\title{
Does China's Middle Class Prefer (Liberal) Democracy?
}

\author{
Wen-Chin $\mathrm{Wu}^{\mathrm{a} 1}$, Yu-Tzung Chang ${ }^{\mathrm{b}}$, and Hsin-Hsin-Pan ${ }^{\mathrm{b}}$ \\ ${ }^{a}$ Institute of Political Science, Academia Sinica, Taipei, Taiwan; \\ ${ }^{b}$ Department of Political Science, National Taiwan University, Taipei, Taiwan
}

\section{Online Appendix}

May 18, 2016

${ }^{1}$ Corresponding author. Email: wenchinwu@ sinica.edu.tw 


\section{Appendix A.1. Operationalization of variables}

\begin{tabular}{|c|c|}
\hline Variables & Coding \\
\hline Preference for Democracy & Principal component score derived by polychoric correlation matrix. \\
\hline c Support & $\begin{array}{l}\text { "Democracy may have its problems, but it is still the best form of } \\
\text { government." 0: Strong disagree or disagree; 1: Strongly agree or } \\
\text { agree. }\end{array}$ \\
\hline Support for Regime Change & $\begin{array}{l}\text { "Compared with other systems in the world, would you say our system } \\
\text { of government works fine as it is, needs minor change, needs major } \\
\text { change, or should be replaced? } 0 \text { : not need to change or needs minor } \\
\text { change; } 1 \text { : need major change or should be replaced. }\end{array}$ \\
\hline Age & Age in years. \\
\hline Male & Coded as 1 if respondents are male, and 0 if female. \\
\hline Education & $\begin{array}{l}\text { 1: under primary education; 2: primary education; } 3 \text { : secondary } \\
\text { education; and 4: university and higher. }\end{array}$ \\
\hline Urban & Coded as 1 if respondents live in an urban area, and 0 otherwise. \\
\hline Economic Evaluation & $\begin{array}{l}\text { "How would you compare the current economic condition of your } \\
\text { family with what it was a few years ago?" 1: much worse now; } 2 \text { a } \\
\text { little worse now; 3: about the same; 4: a little better now; 5: much } \\
\text { better now. }\end{array}$ \\
\hline Perception of National & "How widespread do you think corruption and bribe-taking are in your \\
\hline Corruption & $\begin{array}{l}\text { national government?." -2: Hardly anyone is involved; -1: Not a lot of } \\
\text { officials are corrupt; } 1 \text { : Most officials are corrupt; } 2 \text { : Almost everyone } \\
\text { is corrupt; } 0 \text { : Can't choose or decline to answer. }\end{array}$ \\
\hline Perception of Local & "How widespread do you think corruption and bribe-taking are in your \\
\hline Corruption & $\begin{array}{l}\text { local/municipal government?." }-2 \text { : Hardly anyone is involved; }-1 \text { : Not a } \\
\text { lot of officials are corrupt; } 1 \text { : Most officials are corrupt; } 2 \text { : Almost } \\
\text { everyone is corrupt; } 0 \text { : Can't choose or decline to answer. }\end{array}$ \\
\hline Trust in National & "Please tell me how much trust do you have in the national \\
\hline Government & $\begin{array}{l}\text { Government." }-2 \text { : None at all; }-1 \text { : Not very much trust; } 1 \text { : Quite a lot of } \\
\text { trust; 2: A great deal of trust. } 0 \text { : Do not understand the question, can't } \\
\text { choose, or decline to answer. }\end{array}$ \\
\hline Trust in Local Government & $\begin{array}{l}\text { "Please tell me how much trust do you have in the local Government." } \\
-2 \text { : None at all; -1: Not very much trust; } 1 \text { : Quite a lot of trust; } 2 \text { : A } \\
\text { great deal of trust. 0: Do not understand the question, can't choose, or } \\
\text { decline to answer. }\end{array}$ \\
\hline
\end{tabular}

(continuing on the next page) 


\section{Appendix A.1. Operationalization of variables (Continued)}

Subjective Social Status

"People sometimes think of the social status of their families in terms of being high or low. Imagine a ladder with 10 steps. At step one stand the lowest status and step 10 stand the highest. Where would you place your family on the following scale?" 1: Lowest; 10: Highest.

Middle Class Coded as 1 if the subjective social status is between 4 and 7 (inclusive); otherwise coded as 0 .

Extent of Democracy "How much of a democracy is China? 1: A democracy; 2: A democracy with major problems; 3: A democracy with minor problems; 4: A full democracy. 
Appendix A.2. Summary statistics

\begin{tabular}{lrrrrr}
\hline Variable & N & Mean & Std. Dev. & Min. & Max. \\
\hline Preference for Democracy & 3225 & 44.507 & 29.068 & 0 & 100 \\
Democratic Support & 2780 & 0.890 & 0.313 & 0 & 1 \\
Support for Regime Change & 2705 & 0.280 & 0.449 & 0 & 1 \\
Age & 3225 & 45.242 & 15.577 & 18 & 92 \\
Age^2 & 3225 & 2289.394 & 1470.128 & 324 & 8464 \\
Male & 3225 & 0.534 & 0.499 & 0 & 1 \\
Education & 3225 & 2.510 & 0.869 & 1 & 4 \\
Urban & 3225 & 0.470 & 0.499 & 0 & 1 \\
Subjective Social Status & 3225 & 5.368 & 1.903 & 1 & 10 \\
Subjective Social Status ${ }^{\wedge}$ & 3225 & 32.441 & 20.491 & 1 & 100 \\
Middle Class & 3225 & 0.710 & 0.454 & 0 & 1 \\
Economic Evaluation & 3225 & 3.916 & 0.833 & 1 & 5 \\
Perception of National Corruption & 3225 & -0.481 & 1.020 & -2 & 2 \\
Perception of Local Corruption & 3225 & 0.207 & 1.133 & -2 & 2 \\
Trust in National Government & 3225 & 1.421 & 0.718 & -2 & 2 \\
Trust in Local Government & 3225 & 0.751 & 1.014 & -2 & 2 \\
\hline
\end{tabular}

